\title{
Sea surface temperature constrains wedge-tailed shearwater foraging success within breeding seasons
}

\author{
Darren R. Peck*, Brian V. Smithers, Andrew K. Krockenberger, Bradley C. Congdon
}

School of Tropical Biology, James Cook University, PO Box 6811, Cairns, Queensland 4870, Australia

\begin{abstract}
Processes that underlie impacts of global warming on marine organisms at upper trophic levels are largely unknown. Long-term studies of seabirds indicate that inter-annual decreases in fledging success are correlated with El Niño years, when sea surface temperatures (SSTs) are above long-term averages. These studies propose that seasonal processes are most likely responsible. To date, no work has focused on the potential impacts of elevated SSTs on seabird reproduction at finer time scales, i.e. within a breeding season. We directly measured the influence of SST variability on foraging success in the wedge-tailed shearwater Puffinus pacificus within and among 3 breeding seasons at Heron Island in the southern Great Barrier Reef, Australia. We found that changes in foraging success (meal size and feed frequency) and chick growth were negatively correlated with daily variations in SST both within and among seasons. Our findings suggest that forage resource availability fluctuated daily in direct association with small-scale variation in SST. This is evidence that declines in seabird breeding success, previously coupled exclusively with large-scale El Niño conditions and processes, may also involve fine-scale mechanisms. Consequently, observed El Niño scale impacts may include season-specific outcomes of day-to-day trophic interactions that operate within all breeding seasons.
\end{abstract}

KEY WORDS: Shearwater $\cdot$ Sea surface temperature $\cdot$ SST $\cdot$ Seabirds $\cdot$ Global warming $\cdot$ Foraging success - Temporal-scale

Resale or republication not permitted without written consent of the publisher

\section{INTRODUCTION}

Most studies that examine the impacts of climate change on marine ecosystems do not consider the effects of day-to-day trophic interactions (Francis et al. 1998). However, defining a temporal framework over which climate change processes operate is essential for the continued development of predictive and mechanistic models (Levin 1992, Ives 1995, Stott \& Kettleborough 2002).

Climate models predict that mean annual global temperature will continue to rise until the end of the 21st century (Easterling et al. 2000, Sæther 2000). Increasingly, empirical evidence is being presented that links climate change to significant impacts on both the ecological and life-history characteristics of species
(Harrington et al. 1999, Hughes 2003). Climate change is closely related to large-scale atmospheric phenomena, of which El Niño Southern Oscillation (ENSO) is best known (Cane 1983). A characteristic of El Niño events in tropical locations is the occurrence of above average sea surface temperatures (SSTs) that have been linked to coral bleaching (Hoegh-Guldberg 1999) and changes in the temporal and spatial distribution of a variety of marine organisms at lower trophic levels (eg. zooplankton, sardine and cephalopods; NevarezMartinez et al. 2001, Jackson \& Domeier 2003, Wilson et al. 2003).

The potential impact of above average SSTs on species at higher trophic levels, such as seabirds, is unclear (Oedekoven et al. 2001, Stenseth et al. 2002). Both beneficial and detrimental long-term/seasonal 
impacts on seabird breeding success have been observed in a number of temperate systems (Kitaysky \& Golubova 2000, Hedd et al. 2002, Durant et al. 2003, Gjerdrum et al. 2003). These effects are thought to result from seasonal-scale changes associated with the impact of SST on productivity and prey species abundance (Stenseth et al. 2002, Durant et al. 2003, Inchausti et al. 2003). However, the relationships and mechanisms are unclear, and thought to be complex (Duffy 1993, McGowan et al. 1998, Harrington et al. 1999, Stenseth et al. 2002).

So far, only detrimental long-term/seasonal effects have been observed in tropical systems. Above average SSTs in the Central Pacific during an El Niño event in 1982-83 were associated with reproductive failure and high adult mortality in numerous seabird species (Schreiber \& Schreiber 1984, Ainley et al. 1988, Schreiber 1994). Consequences included lengthened fledgling periods, lower growth rates, decreased nesting success and a reduction in the incidence of breeding (Ainley et al. 1988). More recent work in the tropics has documented similar detrimental impacts of elevated SST at the seasonal scale (Fernandez et al. 2001, Ramos et al. 2002, Schreiber 2002, Smithers et al. 2003).

Two mechanistic hypotheses can be derived from the literature. The first suggests that a change in SSTs (entrained by large-scale processes such as ENSO), cause seasonal-scale declines in productivity at lower trophic levels (Stenseth et al. 2002). Low productivity subsequently impacts on the recruitment of seabird prey species on a seasonal basis (Schreiber \& Schreiber 1984, Cushing 1990, Stenseth \& Mysterud 2002, Stenseth et al. 2002, Durant et al. 2003). By definition, this general model predicts that foraging success during ENSO events should be lower at the beginning of the breeding season and possibly for the duration of the breeding season.

An alternative hypothesis is that fluctuating SSTs within a breeding season reduce accessibility to prey species, by affecting the vertical and/or horizontal distribution of prey. This process could be driven by numerous physiological (Yang et al. 1995), ecological (Kaplan et al. 2003, Mcllwain 2003, McKinnon et al. 2003) and/or behavioural (Spear et al. 2001) factors. As a consequence, prey availability during the breeding season should track changes in SST over shorter temporal scales. Moreover, prey availability would not be depressed for the entire breeding season; instead, fluctuations should occur over the same temporal-scales as variation in SST (i.e. on a daily basis).

Wedge-tailed shearwaters Puffinus pacificus are tube-nosed, burrow nesting seabirds (Procellariidae) that breed on islands throughout the tropics, including coral cays of the Great Barrier Reef (GBR), Australia
(Marchant \& Higgins 1990). Whilst breeding, adults forage during the day on squid (Ommastrephidae), and fish from the Carangidae and Mullidae families (Harrison et al. 1983, Marchant \& Higgins 1990, D. R. Peck \& B. C. Congdon unpubl. data) and return at night to feed chicks. Previously, significant decreases in provisioning rates, growth rates and fledging success have been observed on a seasonal basis in this species, in association with above average SSTs during an ENSO event (Smithers et al. 2003).

The aim of this study was to examine further the effect SST variation has on measures of foraging and breeding success in this species over a much shorter (day-to-day) time period. This was done to establish the temporal scale at which SST variation and breeding success are linked in this system, and to evaluate the relative importance of large versus small-scale temporal mechanisms so as to better understand the relationship between seabird reproductive success, prey availability and environmental change.

\section{MATERIALS AND METHODS}

This study was conducted at Heron Island $\left(23^{\circ} 26^{\prime} \mathrm{S}\right.$ $\left.151^{\circ} 51^{\prime} \mathrm{E}\right)$, in the Capricorn Section of the GBR Marine Park, Australia. Work was undertaken during 3 breeding seasons; 2001, 2002 and 2003. A total of 27 study nests were monitored in 2001, 29 in 2002 and 26 in 2003. These sample sizes included 5 control nests for 2001, 7 for 2002 and 5 for 2003. In all 3 years, adult provisioning rates, chick growth and chick survivorship were monitored at each nest daily. Chicks were weighed twice a day at 09:00 and 16:00 $\mathrm{h}$ using an electronic balance $( \pm 0.1 \mathrm{~g})$. Between these times, no adult visits or chick feeding were observed. Culmen and tarsus measurements were obtained for each chick every $4 \mathrm{~d}$ using dial callipers $( \pm 0.1 \mathrm{~mm})$. At each burrow, both adults were banded for individual recognition and attendance was monitored continuously from 17:00 to 05:00 h daily. During monitoring, burrow entrances were fitted with a sliding trapdoor of clear Perspex that was triggered by adults entering the burrow. After an adult had entered a burrow and chick feeding was complete, as indicated by chicks no longer begging, the visiting adult was captured and identified. After each capture, traps were reset so that subsequent visits by the same or other adults could be detected. In 2003, chick masses were consistently obtained immediately following any adult visit to a nest (a total of 21 nests without controls). These data allowed 3 measures of adult foraging success to be calculated for each study nest during the 3 study years; adult feed frequency $\left(\mathrm{F}_{\mathrm{FREQ}}\right)$, chick daily mass change $\left(\mathrm{C}_{\mathrm{MASS}}\right)$ and chick survivorship, as well as per- 
mitting relative meal mass $\left(\mathrm{M}_{\mathrm{MASS}}\right)$ to be calculated for 2003.

Adult feed frequency $\left(F_{\mathrm{FREQ}}\right)$ and relative meal mass ( $\left.\mathbf{M}_{\text {MAss }}\right)$. The frequency at which adults fed chicks was evaluated for 3 breeding seasons; 2001, 2002 and 2003. An adult feeding visit was defined as an increase in chick mass between the 16:00 h weighing and the time immediately after an adult visit. The number of chicks fed each day was used to calculate the proportion fed from nests being monitored ( $\left.\mathrm{F}_{\mathrm{FREQ}}\right)$.

Meal mass was defined as the difference in chick mass between its 16:00 h weighing and mass immediately following an adult visit. Chick ages were estimated to range between 1 and $10 \mathrm{~d}$, based on a regression of tarsus length against known-age chicks $\left(F_{1,19}=\right.$ 221.15, $\mathrm{p}<0.0001, \mathrm{r}^{2}=0.91$ ). Therefore, to standardise for chick developmental stage, the amount of food received by chicks was divided by chick mass at 16:00 $\mathrm{h}$ (prior to the observed feed for that day). This gave meal mass per $g$ of chick, or relative meal mass. The average relative meal mass ( $\left.\mathrm{M}_{\mathrm{MASS}}\right)$ was then generated for each day of the study period. Handling caused a chick to regurgitate on 1 occasion. This data point was not included in the analysis.

Relative chick daily mass change ( $\left.\mathbf{C}_{\text {MAss }}\right)$. Relative daily mass changes for individual chicks were determined for a total of 82 chicks in 3 breeding seasons (2001, 2002 and 2003) by calculating the mass change over each $24 \mathrm{~h}$ period (i.e. the difference between 2 consecutive 16:00 $\mathrm{h}$ masses). To account for the potential influence of chick developmental stage on mass change, the differences in mass were divided by the chick mass at the start of the $24 \mathrm{~h}$ period to obtain the mass change per $g$ of chick $\left(\mathrm{C}_{\text {MASS }}\right)$. These were then averaged for all chicks for each day of the study period.

SST Data. Daily SST data were obtained from 2 primary sources: (1) mean daily values (calculated from half hour readings) obtained from the Australian Institute of Marine Science, Half-tide Rocks remote weather station $\left(\mathrm{SST}_{\mathrm{HALF}}\right)\left(23^{\circ} 09^{\prime} \mathrm{S} 150^{\circ} 56^{\prime} \mathrm{E}_{;} 125 \mathrm{~km}\right.$ NE of Heron Island) and (2) observed SST at 09:00 h $\left(\mathrm{SST}_{\mathrm{HI}}\right)$ obtained from the Heron Island Research Station $\left(23^{\circ} 26^{\prime} \mathrm{S} 151^{\circ} 51^{\prime} \mathrm{E}\right)$. The 2 measures of SST were highly correlated $\left(F_{1,27}=32.46, \mathrm{p}<0.0001, \mathrm{r}^{2}=0.538\right)$ but the Half-tide Rocks data offered better instrumental resolution $\left(0.1 \mathrm{vs} 0.5^{\circ} \mathrm{C}\right)$ and a more representative measure of the average SST over the entire $24 \mathrm{~h}$ period (i.e. calculated from the mean of half-hourly readings over the previous $24 \mathrm{~h}$, compared to a single daily record of the SST measured at 09:00 h). Therefore, where possible, SST at Half-tide Rocks was used in the analyses as a more representative measure of SST experienced by foraging wedge-tailed shearwaters. Half-tide Rocks data were not available for the 2002 breeding season; therefore, SST data from Heron Island had to be used for inter-annual analyses.

Relationship between daily variations in SST and foraging success. All data were tested for normality and homogeneity of variances. Linear regressions were then calculated where these assumptions were met. Measures of SST over time involve serial autocorrelation. A priori autocorrelation analysis of SST data indicated a significant effect at the scale of 1 day only. To account for this, we employed a conservative approach by reducing the degrees of freedom during significance testing. The dependent variables for these analyses were $\mathrm{F}_{\mathrm{FREQ}}$ and $\mathrm{M}_{\mathrm{MASS}}$. $\mathrm{SST}_{\mathrm{HALF}}$ was the independent variable for within season (2003) analyses, with $\mathrm{SST}_{\mathrm{HI}}$ used for other (i.e. inter-annual) analyses.

Relationship between SST and annual reproductive success. To determine the influence of daily fluctuations in SST on the observed pattern of inter-annual declines in reproductive success, ANCOVA analyses were conducted with $\mathrm{C}_{\text {MASS }}$ and $\mathrm{F}_{\mathrm{FREQ}}$ as the independent variable, year as the factor and $\mathrm{SST}_{\mathrm{HI}}$ as the covariate. All statistical analyses were performed using JMP Version 4.0.2 (SAS Institute).

\section{RESULTS}

Of the 21 study chicks monitored in 2003, 19 survived until the end of the study period. Monitoring of 1 nest began on 13 February 2003, 5 d after the others. The mortality rate of $10 \%$ in this study was lower than that observed during the 2002 breeding season (50\%) at the same colony, but greater than that seen during $2001(3.4 \%)\left(\chi^{2}=60.23, \mathrm{df}=2, \mathrm{p}<0.0001\right)$ (Smithers et al. 2003).

\section{Adult feed frequency and meal mass in 2003}

The proportion of chicks fed each day $\left(\mathrm{F}_{\mathrm{FREQ}}\right)$ and relative meal mass $\left(\mathrm{M}_{\mathrm{MASS}}\right)$, fluctuated over the 2003 study period ( $\mathrm{F}_{\mathrm{FREQ}} F_{2,25}=13.5861, \mathrm{p}=0.0001 ; \mathrm{M}_{\mathrm{MASS}}$ $F_{2,25}=10.0201, p=0.0006$ ) (Fig. 1). Mean $F_{\text {FREQ }}$ for the entire 2003 study period was $0.44 \pm \mathrm{SE} 0.036(\mathrm{n}=28)$. The mean $\mathrm{M}_{\text {MASS }}$ for the same period was $0.142 \mathrm{~g} \pm \mathrm{SE}$ $0.013(\mathrm{n}=28)$ per $\mathrm{g}$ of chick. Both were significantly lower during the period 19 to 26 February 2003 (inclusive). After this time, foraging success began to increase (Fig. 1).

\section{Foraging success in relation to SST in 2003}

Relative meal mass ( $\left.\mathrm{M}_{\mathrm{MASS}}\right)$ was negatively correlated with SST at Half-tide Rocks $\left(\mathrm{SST}_{\mathrm{HALF}}\right)$ (Fig. 2a) 


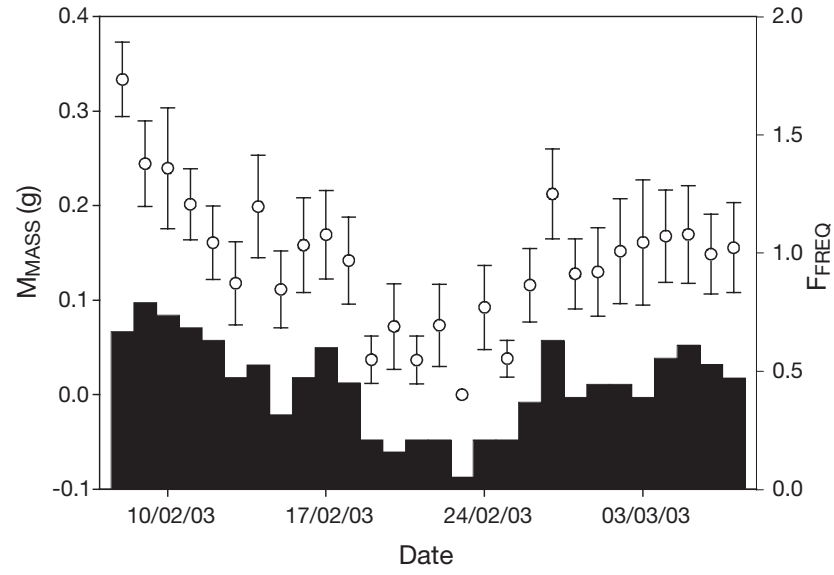

Fig. 1. Puffinus pacificus. Mean $( \pm \mathrm{SE})$ relative daily meal mass $\left(\mathrm{M}_{\mathrm{MASS}}, \mathrm{O}\right)$ and proportion of young fed each day $\left(\mathrm{F}_{\mathrm{FREQ}}\right.$ shaded bars) for wedge-tailed shearwaters at Heron Island February-March 2003
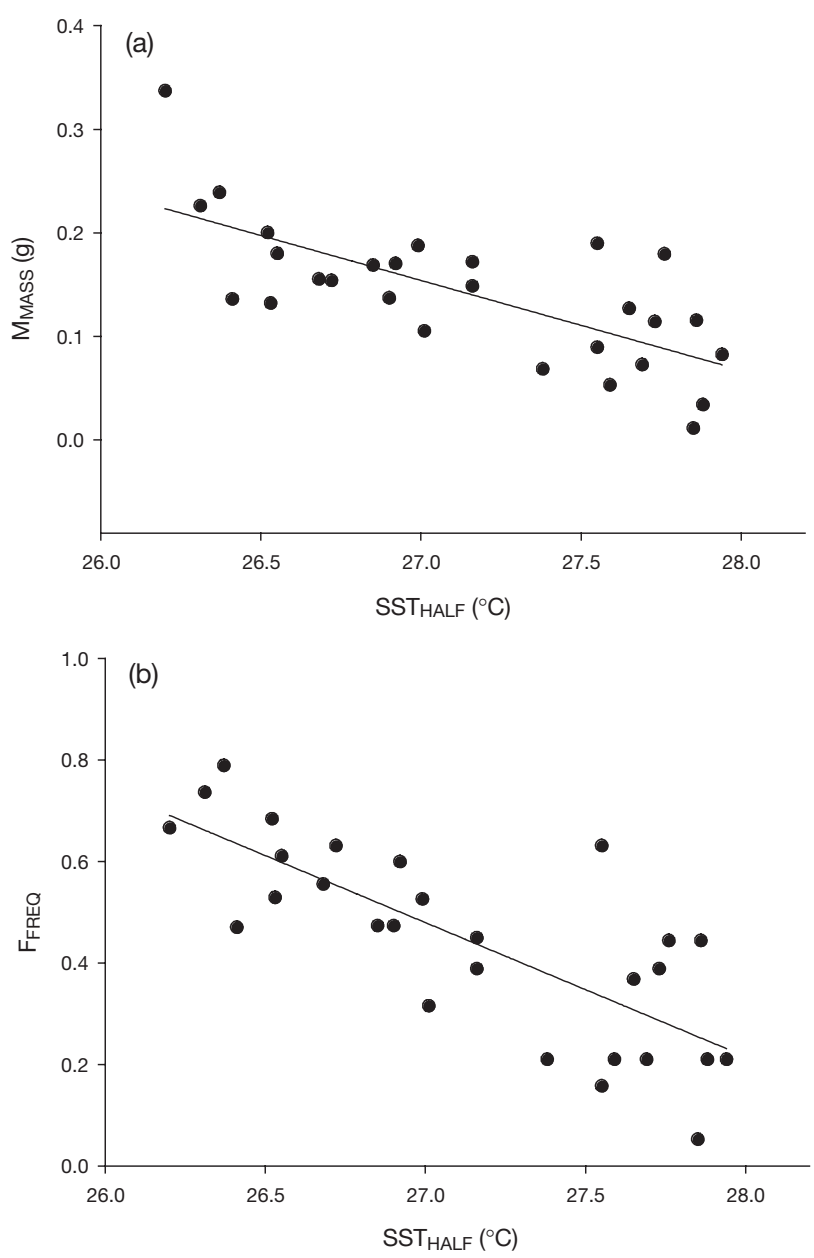

Fig. 2. Puffinus pacificus. Relationship between sea surface temperature at Half-tide Rocks ( $\mathrm{SST}_{\mathrm{HALF}}$ ) and (a) relative meal mass $\left(\mathrm{M}_{\mathrm{MASS}}\right)$ and (b) $\mathrm{F}_{\mathrm{FREQ}}$ during the $28 \mathrm{~d}$ study period in $2003\left(\mathrm{M}_{\mathrm{MASS}}=2.497-0.086 \mathrm{SST}_{\mathrm{HALF}} \mathrm{F}_{\mathrm{FREQ}}=7.615-0.264\right.$ $\mathrm{SST}_{\text {HALF }}$
$\left(F_{1,26}=27.67, \mathrm{p}<0.0001, \mathrm{r}^{2}=0.497\right)$. For each $1^{\circ} \mathrm{C}$ increase in SST, M MASS decreased by approximately $0.086 \mathrm{~g}$ per $\mathrm{g}$ chick mass (Fig. 2a). For a $100 \mathrm{~g}$ chick, this is equivalent to a decrease of $\sim 8.6 \mathrm{~g}$ per $1^{\circ} \mathrm{C}$.

Feeding frequency $\left(\mathrm{F}_{\mathrm{FREQ}}\right)$ was also negatively correlated with SST at Half-tide Rocks for the 2003 study period (Fig. 2b) $\left(F_{1,28}=38.233, \mathrm{p}=0.0001, \mathrm{r}^{2}=0.579\right)$. The proportion of chicks that were fed in a single night decreased by approximately $26.4 \%$ per $1^{\circ} \mathrm{C}$ increase in SST between 26 and $28^{\circ} \mathrm{C}$. This is equivalent to each chick being fed on average 1 night in 2 when SST = $27^{\circ} \mathrm{C}$, but only 1 night in 3 when $\mathrm{SST}=27.6^{\circ} \mathrm{C}$ (the long-term seasonal average temperature) and only 1 night in 5 when $\mathrm{SST}=28^{\circ} \mathrm{C}$.

\section{Relative chick daily mass change ( $\left.\mathrm{C}_{\text {MASS }}\right)$ in 2003 and among years}

The mean relative daily change in chick mass $\left(\mathrm{C}_{\text {MASS }}\right)$ during the 2003 study period was $0.0349 \mathrm{~g} \pm$ 0.0102 ( $\mathrm{n}=28$ ). Unlike $\mathrm{M}_{\text {MASS }}$ and $\mathrm{F}_{\mathrm{FREQ}}, \mathrm{C}_{\text {MASS }}$ was not significantly depressed during the period 19 to 26 February $2003\left(F_{2,24}=2.46, \mathrm{p}=0.10\right)$. However, $\mathrm{C}_{\text {MASS }}$ was negatively correlated with $\operatorname{SST}_{\text {HALF }}\left(F_{1,25}=5.31, \mathrm{p}=\right.$ $\left.0.0297, r^{2}=0.175\right)$ and shows zero or negative growth at $28^{\circ} \mathrm{C}$ (Fig. 3).

There was a significant negative effect of $\mathrm{SST}_{\mathrm{HI}}$ on $\mathrm{C}_{\text {MASS }}$ for all years (Fig. $\left.4 \mathrm{a}\right)\left(F_{5,66}=6.09, \mathrm{r}^{2}=0.264, \mathrm{p}=\right.$ $0.0001)$. There was also an effect of year on $\mathrm{C}_{\text {MASS }}$ $\left(F_{1,66}=8.438, \mathrm{p}=0.0005\right)$; however, the slopes of the regression lines for each year were not significantly different from each other $\left(F_{1,66}=0.0186, \mathrm{p}=0.9816\right)$. Thus, in all $3 \mathrm{yr}$, chick mass change declined at the same rate with increasing $\mathrm{SST}$, but in 2002 the average amount of chick growth per $g$ of chick was less at any given SST (Fig. 4a).

As with mean relative mass change, $F_{F R E Q}$ was also significantly correlated with $\mathrm{SST}_{\mathrm{HI}}$ among years (Fig. $4 b, F_{5,62}=10.92$, $\mathrm{p}<0.0001, \mathrm{r}^{2}=0.425$ ), with a significant effect of year on mean mass change $\left(F_{1,2}=\right.$ 13.696, $\mathrm{p}<0.0001$ ) but with no difference among the slopes of the regression lines for each year (Fig. 4 b, $F_{1,2}$ $=0.5805, p=0.5626)$. Results suggest that among years, SST affected feeding frequency in the same way that it affected chick mass changes; feeding decreased at the same rate in all 3 seasons, except that during 2002, feed frequency for a given SST was consistently lower.

We observed autocorrelation in our SST data at the scale of $1 \mathrm{~d}$. This effectively reduces the number of independent data points in our analyses by 1 and so requires a similar reduction in the associated degrees of freedom. On testing the robustness of our results, we found that the significance of all regression analyses, except SST versus $\mathrm{C}_{\text {MASs, }}$ did not change when 


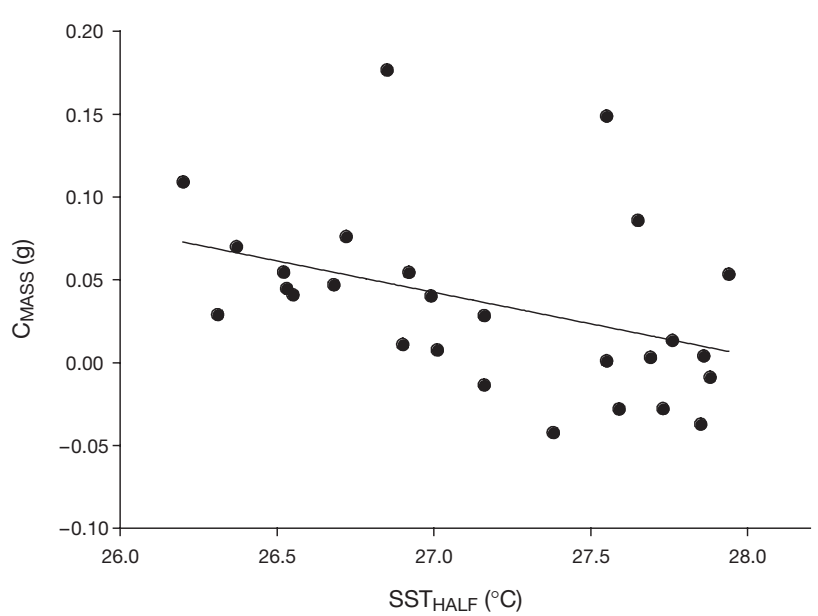

Fig. 3. Puffinus pacificus. Relationship between relative daily change in chick mass $\left(\mathrm{C}_{\mathrm{MASS}}\right)$ and $\mathrm{SST}_{\mathrm{HALF}}$ during the 2003 study period $\left(\mathrm{C}_{\mathrm{MASS}}=1.128-0.040 \mathrm{SST}_{\mathrm{HALF}}\right)$

degrees of freedom were reduced by up to 14 . The SST versus $\mathrm{C}_{\text {MASS }}$ regression remained significant with a reduction of up to 4 degrees of freedom. Therefore, since only a 1 degree reduction is required for the level of autocorrelation observed, we are confident that our findings are not affected by this phenomenon.

\section{DISCUSSION}

Both the frequency at which Heron Island wedgetailed shearwater chicks were fed and the meal mass delivered by adults were highly variable during the 2003 study period with a marked decrease during the period 18 to 27 February 2003 (Fig. 1). This decrease was followed by a steady increase (Fig. 1) and indicates that prey species available to adults feeding chicks were depressed during the period 18 to 27 February 2003. Also, in 2003 both feeding frequency and chick meal mass were strongly negatively correlated with daily variation in $\mathrm{SST}_{\text {HALF }}$ (Fig. 2). Chick growth was also correlated with $\mathrm{SST}_{\mathrm{HALF}}$ (Fig. 3). Furthermore, feed frequency and chick growth were correlated with $\mathrm{SST}_{\mathrm{HI}}$ on a daily basis in all 3 breeding seasons (Fig. 4). Therefore, small-scale daily fluctuations in SST significantly and consistently impacted both the foraging success and chick growth of wedge-tailed shearwaters both within and among breeding seasons at Heron Island.

Annual or decadal variation in SST have often been correlated with fluctuations in seabird reproductive success (Francis et al. 1998) and have generally been framed in the context of large-scale (both spatial and temporal) atmospheric processes such as ENSO (in the Pacific Ocean) or NAO (in the North Atlantic Ocean)
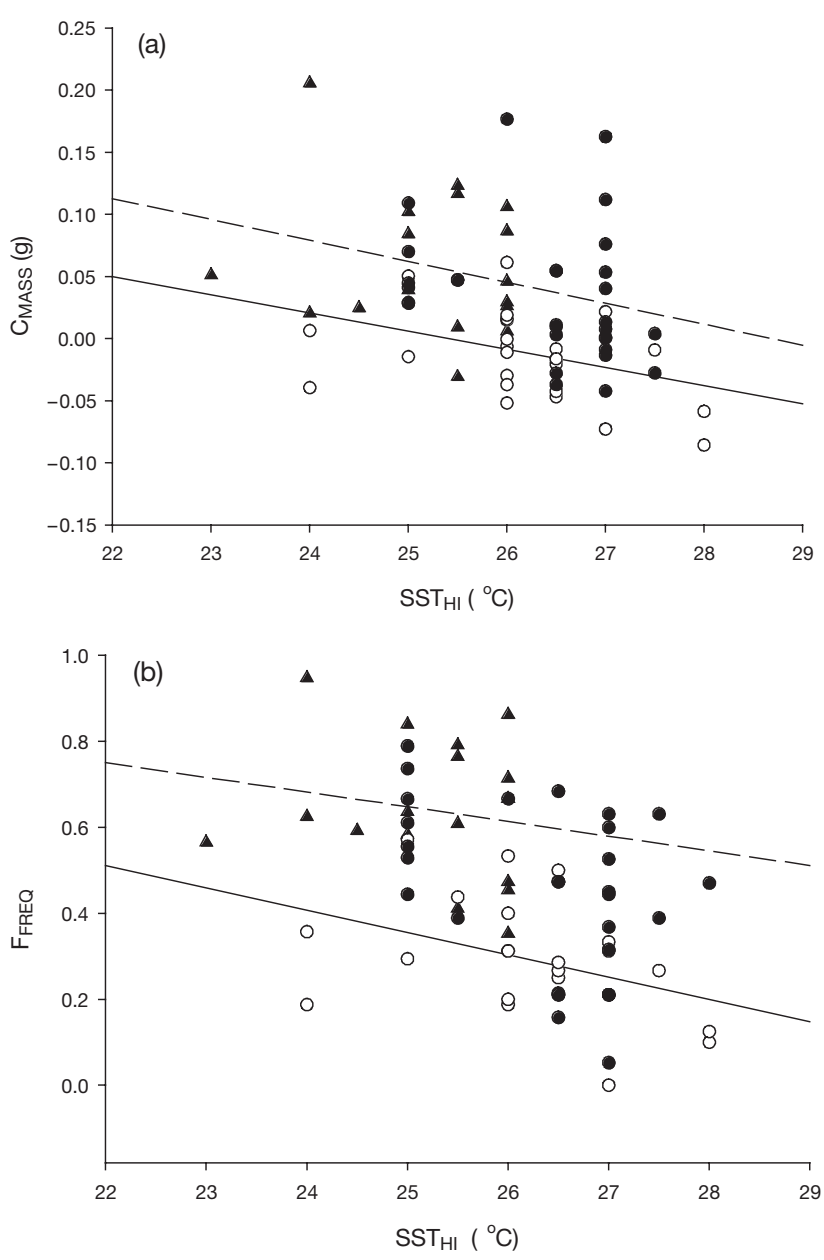

Fig. 4. Puffinus pacificus. (a) Effect of sea surface temperature

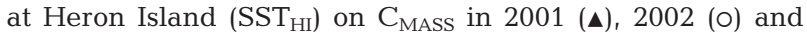
$2003(\bullet)$. There was a significant effect of $\mathrm{SST}_{\mathrm{HI}}$ on $\mathrm{C}_{\mathrm{MASS}}$ among years $\left(\mathrm{C}_{\mathrm{MASS}}=0.533-0.0195 \mathrm{SST}_{\mathrm{HI}}\right)$. The effect of year on $\mathrm{C}_{\text {MASS }}$ was also significant. There was no effect of year on $\mathrm{SST}_{\mathrm{HI}}$. (b) The effect of $\mathrm{SST}_{\mathrm{HI}}$ on $\mathrm{F}_{\mathrm{FREQ}}$ in 2001 (ム), 2002 (0) and $2003(\bullet)$. There was a significant effect of $\operatorname{SST}_{\mathrm{HI}}$ on $\mathrm{F}_{\mathrm{FREQ}}$ among years $\left(\mathrm{F}_{\mathrm{FREQ}}=2.856-0.092 \mathrm{SST}_{\mathrm{HI}}\right)$. The effect of year on $\mathrm{F}_{\mathrm{FREQ}}$ was also significant. There was no effect of year on $\mathrm{SST}_{\mathrm{HI}}$. In both graphs, the dashed line represents the 2001/2003 regression. 2002 regressions are represented by a solid line

(Cushing 1990, Ainley et al. 1995, Ramos et al. 2002, Durant et al. 2003). It is thought that unfavourable SSTs, in some cases, can disrupt or block nutrient rich up-welling zones, thereby disrupting phytoplankton distribution and abundance (McGowan et al. 1998, Kaplan et al. 2003, Wilson et al. 2003). This in turn causes decreased productivity at higher trophic levels (Sanchez-Velaso et al. 2000, Stenseth et al. 2002). Work in temperate systems has expanded this model by showing that SSTs during the spawning and/or juvenile life-history stages of prey species can impact seabird breeding success via phenological 'mismatches' be- 
tween prey recruitment and the chick rearing period (Cushing 1990, Stenseth \& Mysterud 2002).

However, phenological 'mismatches' involve withinseason time lags between shifting SSTs and the availability of prey species to seabirds (Stenseth \& Mysterud 2002, Durant et al. 2003). Moreover, this mechanism predicts that food availability should be consistently lower and/or delayed during the beginning of the breeding season when a reliable food source is needed for young chicks. We observed fluctuating foraging success on a daily basis (Fig. 1) and no time lag within seasons (Fig. 4), indicating that other factors were operating within the system over much shorter temporalscales. This is evidence that decreases in seabird breeding success, previously correlated with elevated SSTs at the seasonal/yearly scale (Schreiber \& Schreiber 1984, Guinet et al. 1998, Ramos et al. 2002, Smithers et al. 2003), may not exclusively involve largescale, inter-annual processes such as ENSO. Instead, these impacts may involve cumulative effects of day-today trophic interactions that operate within each breeding season. If so, long-term decreases in breeding success that have been linked to ENSO may also involve mechanisms operating on much shorter temporalscales than previously thought (e.g. Cruz \& Cruz 1990, Veit et al. 1997, Guinet et al. 1998, Ramos et al. 2002).

Nevertheless, during the 2002 season, when substantially greater chick mortality was observed (50\%), feeding rates and chick growth were lower than during the other seasons, even when taking into account the daily effect of SST (Fig. 4). This indicates that a seasonal-scale process may also be operating to depress foraging success and growth rates, in addition to the observed within-season effect of SST (Fig. 4). We, therefore, suggest that while the general large-scale seasonal model described above may still be the primary mechanism driving seabird mortality events, it can be significantly enhanced by the addition of possible 'day-to-day' mechanisms.

To our knowledge, there are 2 previously described trophic mechanisms that may influence forageresource availability on a 'day-to-day' basis. The first incorporates the physiological requirements of seabird prey species. The distribution of seabird prey species is known to change in accordance with temperaturedependent physiological requirements (Castillo et al. 1996, Waluda et al. 2001). This can occur in both vertical and/or horizontal space and affects the accessibility of prey to foraging seabirds (Le Corre 2001, Spear et al. 2001). However, this mechanism has previously been viewed as a link to seabird breeding success (via SST change) only at seasonal scales (Maravelias 1997 , Kitaysky \& Golubova 2000, Navarez-Martinez et al. 2001, Takahashi et al. 2001). This is despite work in the Southern Ocean showing that seabird/prey abundance is strongly associated with SSTs measured on a daily basis (Pakhomov \& McQuaid 1996) and data linking short-term (weekly) fluctuations in prey availability with chick provisioning and growth rates (Suryan et al. 2002). Therefore, if prey species prefer specific temperature regimes, it is reasonable to assume that rapid movement in vertical and/or horizontal space to preferred temperatures could decrease their accessibility to aerial predators. In general, the impact on prey species of short-term SST changes is unknown. Our results suggest that they may be considerable and need to be incorporated into mechanistic models defining ENSO related decreases in seabird breeding success at tropical locales.

A second possible 'day-to-day' mechanism is that SST directly influences the abundance of subsurface predators (Le Corre 2001, Ramos et al. 2002). These predators drive prey to the surface, making them available to seabirds (Brown 1980, Shealer 1996, Balance \& Pitman 1999). The most important predators associated with this behaviour in the tropical Pacific Ocean are tuna Thunnus spp. (Ashmole \& Ashmole 1967, Harrison \& Seki 1987). Extensive work has documented a close relationship between foraging seabirds and tuna (Harrison \& Seki 1987, Balance et al. 1997), and it is generally accepted that oceanographic conditions (such as SST) are important to the ecology of this group (Lehodey et al. 1997, Lu et al. 2001, Brill et al. 2002). However, the complex relationships among tuna and oceanographic variation remains poorly understood (Harrison \& Seki 1987, Lehodey et al. 1997, Lu et al. 2001). Consequently, the applicability of this mechanism to wedge-tailed shearwaters remains unclear, but warrants further research.

In conclusion, it has been known for some time that ENSO/NAO driven inter-annual fluctuations in SST can have significant negative impacts on reproductive characteristics of tropical seabirds (Schreiber \& Schreiber 1984, Cruz \& Cruz 1990, Guinet et al. 1998, Ramos et al. 2002, Schreiber 2002). However, to date, studies have considered this to be due solely to productivity decreases and phenological 'mismatches' at the seasonal scale. Our study demonstrates the importance of daily fluctuations in SST on the foraging success of a seabird species, indicating that important processes may also act at finer temporal scales. Our findings imply that to fully understand the potential impact of elevated SSTs on seabird reproduction, work is also needed that identifies the effects of short-term variation in SST on breeding success within and between seasons. In addition, our findings expand research for underlying mechanisms to include withinseason SST effects on prey distribution and abundance, as well as correlated variation in commensal predatory fish distributions. 
Acknowledgements. We thank the staff of the Heron Island Research Station for logistical support during the field components of this project, Y. Peck for field assistance and J. Landsberg for comments on the manuscript. Thanks also to J. Lough (A.I.M.S) and D. Logan (H.I.R.S) for providing SST data. This research was funded by a James Cook University Merit Research Grant (MRG-02/0026), The Ecological Society of Australia and Reef C.R.C. Work was authorised under QNPWS Permits C6/000175/00/SAA \& C6/000195/01/SAA and James Cook University-Ethics Approval A627_00.

\section{LITERATURE CITED}

Ainley DG, Carter HR, Anderson DW, Briggs KT and 8 others (1988) ENSO effects on Pacific Ocean marine bird populations In: Ouelette $\mathrm{H}$ (ed) Acta 19th Congressus Internationalis Ornithologici. University of Ottawa Press, Ottawa, p1747-1758

Ainley DG, Sydeman WJ, Norton J (1995) Upper trophic level predators indicate interannual negative and positive anomalies in the California current food web. Mar Ecol Prog Ser 118:69-79

Ashmole NP, Ashmole M J (1967) Comparative feeding of seabirds of a tropical oceanic island. Bull Peabody Museum of Natural History 24:1-131

Ballance LT, Pitman RL (1999) Foraging ecology of tropical seabirds In: Adams NJ, Slotow RH (eds) Proc 22nd Int Ornithol Congr, Birdlife South Africa, Johannesburg, p 2057-2071

Ballance LT, Pitman RL, Reilly SB (1997) Seabird community structure along a productivity gradient-importance of competition and energy constraint. Ecology 78:1502-1518

Brill R, Lutcavage M, Metzger G, Bushnell P, Arendt M, Lucy J, Watson C, Foley D (2002) Horizontal and vertical movements of juvenile bluefin tuna (Thunnus thynnus), in relation to oceanographic conditions of the western North Atlantic, determined with ultrasonic telemetry. Fish Bull 100:155-167

Brown RGB (1980) Seabirds as marine animals In: Burger J, Olla BL, Winn HE (eds) Behaviour of marine animals. Plenum Press, New York, p 1-39

Cane MA (1983) Oceanographic events during El Niño. Science 222:1189-1202

Castillo J, Barbieri MA, Gonzalez A (1996) Relationships between sea surface temperature, salinity, and pelagic fish distribution off northern Chile. J Mar Sci 53:153-146

Cruz JB, \& Cruz F (1990) Effect of El Niño-Southern Oscillation conditions on nestling growth rate in the darkrumped petrel. Condor 92:160-165

Cushing DH (1990) Plankton production and year-class strength in fish populations: an update of the matchmismatch hypothesis. Adv Mar Biol 26:249-293

Duffy DC (1993) Stalking the Southern Oscillation: environmental uncertainty, climate change, and North Pacific seabirds In: Vermeer K, Briggs KT, Morgan KH, SiegelCausey D (eds) The status, ecology, and conservation of marine birds of the North Pacific, Can Wildl Serv Spec Publ, Ottawa. p 61-67.

Durant JM, Anker-Nilssen T, Stenseth NC (2003) Trophic interactions under climate change fluctuations: the Atlantic puffin as an example. Proc R Soc Lond B 270: 1461-1466

Easterling DR, Meehl GA, Parmesan C, Changnon SA, Karl TR, \& Mearns LO (2000) Climate extremes: observations, modeling and impacts. Science 289:2068-2074

Fernandez P, Anderson DJ, Sievert PR, Huyvaert KP (2001)
Foraging destinations of three low-latitude albatross. J Zool Lond 254:391-404

Francis RC, Hare SR, Hollowed AB, Wooster WS (1998) Effects of interdecadal climate variability on the oceanic ecosystems of the NE Pacific. Fish Oceanogr 7:1-21

Gjerdrum C, Vallée AMJ, Cassady St Clair C, Bertram DF, Ryder JL, Blackburn GS (2003) Tufted puffin reproduction reveals ocean climate variability. Proc Natl Acad Sci USA 100:9377-9382

Guinet C, ChastelO, Koudil M, Durbec JP, Jouventin P (1998) Effects of warm sea surface temperature anomalies on the blue petrel at the Kerguelen Islands. Proc R Soc Lond B 265:1001-1006

Harrington R, Woiwod I, Sparks T (1999) Climate change and trophic interactions. Trends Ecol Evol 14:146-150

Harrison CS, Seki MP (1987) Trophic relationships among seabirds at the Hawaiian Islands In: Croxall JP (ed) Seabirds feeding ecology and role in marine ecosystems. Cambridge University Press, Cambridge, p 301-326

Harrison CS, Hida TS Seki MP (1983) Hawaiian seabird feeding ecology. Wildl Monogr 85:1-71

Hedd A, Ryder JL, Cowen LL, Bertram DF (2002) Inter-annual variation in the diet, provisioning and growth of Cassin's auklet at Triangle Island, British Columbia: responses to variation in ocean climate. Mar Ecol Prog Ser 229:221-232

Hoegh-Guldberg O (1999) Climate change, coral bleaching and the future of the world's coral reefs. Mar Freshw Res 50:839-866

Hughes L (2003) Climate change and Australia: trends, projections and impacts. Austral Ecol 28:423-443

Inchausti P, Guinet C, Koudil M, Durbec JP, Barbraud C, Weimerskirch H, Cherel Y, Jouventin P (2003) Interannual variability in the breeding performance of seabirds in relation to oceanographic anomalies that affect the Crozet and the Kerguelen sectors of the southern ocean. J Avian Biol 34:170-176

Ives AR (1995) Predicting the response of populations to environmental change. Ecology 76:926-941

Jackson GD, Domeier ML (2003) The effects of an extraordinary El Niño/La Niña event on the size and growth of the squid Loligo opalescens off Southern California. Mar Biol 142:925-935

Kaplan DM, Largier JL, Navarrete S, Guiñez R, Castilla JC (2003) Large diurnal temperature fluctuations in the nearshore water column. Estuar Coast Shelf Sci 57:385-398

Kitaysky AS, Golubova EG (2000) Climate change causes contrasting trends in reproductive performance of planktivorous and piscivorous alcids. JAnim Ecol 69:248-262

Le Corre M (2001) Breeding seasons of seabirds at Europa Island (southern Mozambique Channel) in relation to seasonal changes in the marine environment. J Zool 254:239-249

Lehodey P, Bertignac M, Hampton J, Lewis A, Picaut J (1997) El Niño Southern Oscillation and tuna in the western Pacific. Nature 389:715-718

Levin SA (1992) The problem of pattern and scale in ecology. Ecology 73:1943-1967

Lu HJ, Lee KT, Lin HL, Liao CH (2001) Spatio-temporal distribution of yellowfin tuna (Thunnus albacares) and bigeye tuna (Thunnus obesus) in the tropical Pacific Ocean in relation to large-scale temperature fluctuation during ENSO episodes. Fish Sci 67:1046-1052

Maravelias CD (1997) Trends in abundance and geographic distribution of North Sea herring in relation to environmental factors. Mar Ecol Prog Ser 159:151-164

Marchant S, Higgins PJ (1990) Handbook of Australian, New Zealand \& Antarctic birds. Oxford University Press, Melbourne 
McGowan JA, Cayan DR, Dorman LM (1998) Climate-Ocean variability and ecosystem response in the Northeast Pacific. Science 281:210-217

McIlwain JL (2003) Fine-scale temporal and spatial patterns of larval supply to a fringing reef in Western Australia. Mar Ecol Prog Ser 252:207-222

McKinnon AD, Meekan MG, Carleton JH, Furnas MJ, Duggan S, Skirving W (2003) Rapid changes in shelf waters and pelagic communities on the southern Northwest Shelf, Australia, following a tropical cyclone. Cont Shelf Res 23:93-111

Nevarez-Martinez MO, Lluch-Belda D, Cisneros-Mata MA, Santos-Molina JP (2001) Distribution and abundance of the Pacific sardine (Sardinops sagax) in the Gulf of California and their relationship with the environment. Prog Oceanogr 49:565-580

Oedekoven CS, Ainley DG, Spear LB (2001) Variable responses of seabirds to change in marine climate: California Current, 1985-1994. Mar Ecol Prog Ser 212:265-281

Pakhomov EA, McQuaid CD (1996) Distribution of surface zooplankton and seabirds across the Southern Ocean. Polar Biol 16:271-286

Ramos JA, Maul AM, Ayrton V, Bullock I and 5 others (2002) Influence of local and large-scale weather events and timing of breeding on tropical roseate tern reproductive parameters. Mar Ecol Prog Ser 243:271-279

Sæther B (2000) Weather ruins winter vacations. Science 288: 1975-1976

Sanchez-Velaso L, Shirasago B, Cisneros-Mata MA, AvalosGarcia C (2000) Spatial distribution of small pelagic fish larvae in the Gulf of California and its relation to the El Niño 1997-1998. J Plankton Res 22:1611-1618

Schreiber EA (1994) El Niño-Southern Oscillation effects on chick provisioning and growth in red-tailed tropic birds. Colon Waterbirds 17:105-119

Schreiber EA (2002) Climate and weather effects on seabirds In: Schreiber EA \& Burger J (eds) Biology of marine birds. CRC Press, New York, p 179-215

Schreiber RW, Schreiber EA (1984) Central Pacific seabirds and the El Niño southern oscillation: 1982 to 1983 perspectives. Science 225:713-716

Shealer DA (1996) Foraging habitat use and profitability in tropical Roseate Terns and Sandwich Terns. Auk 113: 209-217

Smithers BV, Peck DR, Krockenberger AK, Congdon BC
(2003) Elevated sea surface temperature and reproductive failure of wedge-tailed Shearwaters (Puffinus pacificus) in the Southern Great Barrier Reef, Australia. Mar Freshw Res 54:973-977

Spear LB, Ballance LT, Ainley DG (2001) Response of seabirds to thermal boundaries in the tropical Pacific: the thermocline versus the Equatorial Front. Mar Ecol Prog Ser 219: 275-289

Stenseth NC, Mysterud A (2002) Climate, changing phenology, and other life history traits: nonlinearity and matchmismatch to the environment. Proc Natl Acad Sci USA 99: 13379-13381

Stenseth NC, Mysterud A, Ottersen G, Hurrell JW, Chan KS, Lima M (2002) Ecological effects of climate fluctuations. Science 297:1292-1296

Stott PA, Kettleborough JA (2002) Origins and estimates of uncertainty in predictions of twenty-first century temperature rise. Nature 416:719-723

Suryan RM, Irons DB, Kaufman M, Benson J, Jodice PGR, Roby DD, Brown ED (2002) Short-term fluctuations in forage fish availability and the effect on prey selection and brood-rearing in the black-legged kittiwake Rissa tridactyla. Mar Ecol Prog Ser 236:273-287

Takahashi A, Kuroki M, Niizuma Y, Kato A, Saitoh S, Watanuki Y (2001) Importance of the Japanese anchovy (Engraulis japonicus) to breeding rhinoceros auklets, (Cerorhinca monocerata) on Teuri Island, Sea of Japan. Mar Biol 139:361-371

Veit RR, McGowan JA, Ainley DG, Wahl TR, Pyle P (1997) Apex marine predator declines ninety percent in association with changing oceanic climate. Global Change Biol 3:23-28

Waluda CM, Rodhouse PG, Podesta GP, Trathan PN, Pierce GJ (2001) Surface oceanography of the inferred hatching grounds of Illex argentinus (Cephalopoda: Ommastrephidae) and influences on recruitment variability. Mar Biol 139:671-679

Wilson SG, Carleton JH, Meekan MG (2003) Spatial and temporal patterns in the distribution and abundance of macrozooplankton on the southern North West Shelf, Western Australia. Estuar Coast Shelf Sci 56:897-908

Yang JM, Gu CC, Li LY, Gao CY, Li WZ (1995) Satellite remote sensing prediction of Japanese pilchard fishing ground in the Huanghai Sea and the East China Sea. Sci China Ser B 38:336-344

Submitted: April 23, 2004; Accepted: July 8, 2004

Proofs received from author(s): October 20, 2004
Editorial responsibility: Otto Kinne (Editor),

Oldendorf/Luhe, Germany 